\title{
Editorial: Perspectives on Carbon Dioxide Capture and Conversion
}

\author{
Diana C. S. Azevedo ${ }^{1 *}$, Sebastiao M. P. Lucena ${ }^{1}$, Enrique Rodríguez-Castellón ${ }^{2}$ and \\ Carlos Wexler ${ }^{3}$ \\ ${ }^{1}$ Federal University of Ceara, Fortaleza, Brazil, ${ }^{2}$ University of Malaga, Málaga, Spain, ${ }^{3}$ University of Missouri, Columbia, $K Y$, \\ United States
}

Keywords: $\mathrm{CO}$, activated carbon, mesoporous silica, additive manufacturing, aluminophosphate molecular sieves, techno-economic analysis, ZIF-8

\section{Editorial on the Research Topic}

\section{Perspectives on Carbon Dioxide Capture and Conversion}

If we were to establish a year for the discovery of global warming caused by the concentration of greenhouse gases in the atmosphere, this year is 1988. In the summer of that year, the highest temperatures in the historical series of data collected so far were recorded. Moreover, atmospheric simulators had become so accurate that all existing models, validated from the reproduction of climate historical records, showed significant global warming when greenhouse gases were added (Weart, 2008). Today, more than 30 years later, the scientific community has produced a huge knowledge base around $\mathrm{CO}_{2}$ capture materials and processes, and the present research topic offers a nice sample of such efforts. From the point of view of materials, we present

\section{OPEN ACCESS}

Edited and reviewed by: Valeria Conte,

University of Rome Tor Vergata, Italy

*Correspondence:

Diana C. S. Azevedo

diana@gpsa.ufc.br

Specialty section:

This article was submitted to Green and Sustainable Chemistry, a section of the journal Frontiers in Chemistry

Received: 06 February 2021 Accepted: 15 February 2021

Published: 14 April 2021

Citation:

Azevedo DCS, Lucena SMP Rodríguez-Castellón E and Wexler $C$

(2021) Editorial: Perspectives on

Carbon Dioxide Capture and Conversion.

Front. Chem. 9:664979.

doi: 10.3389/fchem.2021.664979 the prospects of conventional materials such as activated carbons, tailored to capture $\mathrm{CO}_{2}$ either as synthesized (Prauchner et al.) or by post-synthesis impregnation (Giraldo et al.). Mesoporous silicas belong to the group of very stable materials with a low $\mathrm{CO}_{2}$ adsorption capacity per se; however, they are preferential candidates for functionalization with amino silanes, which considerably increase their $\mathrm{CO}_{2}$ capture capacity (Vilarrasa-García et al.). The research topic also includes materials that weakly bind $\mathrm{CO}_{2}$ while keeping a relatively high uptake, such as the aluminum phosphate molecular sieves (Pérez-Botella et al.). Important techno-economic considerations of capture processes are considered (Danaci et al.), and the state of art of $\mathrm{CO}_{2}$ capture via mineralization of steel slag (Zhao et al.) is presented. Finally, new bed-forming techniques based on additive manufacturing are presented using the new material ZIF-8 (Verougstraete et al.) from the class of metal-organic frameworks (MOFs).

We hope that this collection will be useful both as an introduction to the subject of $\mathrm{CO}_{2}$ capture and as a relevant showcase of the latest research associated with the topic.

\section{AUTHOR CONTRIBUTIONS}

SL wrote the first draft. DA, ER-C, and CW revised the editorial.

\section{REFERENCES}

Weart, S. R. (2008). The discovery of global warming. Cambridge, MA: Harvard University Press. 
Conflict of Interest: The authors declare that the research was conducted in the absence of any commercial or financial relationships that could be construed as a potential conflict of interest.

Copyright (c) 2021 Azevedo, Lucena, Rodríguez-Castellón and Wexler. This is an open-access article distributed under the terms of the Creative
Commons Attribution License (CC BY). The use, distribution or reproduction in other forums is permitted, provided the original author(s) and the copyright owner(s) are credited and that the original publication in this journal is cited, in accordance with accepted academic practice. No use, distribution or reproduction is permitted which does not comply with these terms. 